\title{
Specific factors influence the success of autologous and allogeneic hematopoietic stem cell transplantation
}

\author{
Thissiane L. Gonçalves, * Dalila M. Benvegnú and Gabriela Bonfanti \\ Departamento de Análises Clínicas e Toxicológicas; CCS; Universidade Federal de Santa Maria; Santa Maria RS, Brazil
}

\begin{abstract}
Abbreviations: AA, aplastic anemia; BCNU, carmustine; BMT, bone marrow transplantation; CR, conditioning regimen; G-CSF, granulocyte-colony-stimulating factor; GVHD, graft-versus-host disease; HSCT, hematopoietic stem cell transplantation; M-200, melphalan; MM, multiple myeloma; OS, overall survival; PBSCT, peripheral blood stem cell transplantation; SMD, syndrome myelodysplastic; TBI, total body irradiation; VP-16, etoposide
\end{abstract}

Key words: engraftment, hematopoietic stem cell transplantation, peripheral blood stem cell transplantation, bone marrow transplantation, conditioning regimen

Successful hematopoietic stem cell transplantation (HSCT), both autologous and allogeneic, requires a rapid and durable engraftment, with neutrophil $(>500 / \mu \mathrm{L})$ and platelet $(>20,000 /$ $\mu \mathrm{L})$ reconstitution. Factors influencing engraftment after autologous or allogeneic HSCT were investigated in 65 patients: 25 autologous peripheral stem cell transplantation (PBSCT) and 40 allogeneic bone marrow transplantation (BMT) patients. The major factor affecting engraftment was the graft source for HSCT. Neutrophil and platelet recovery were more rapid in autologous PBSCT than in allogeneic BMT [neutrophil occurring in median on day $10.00(09.00 / 11.00)$ and $19.00(16.00 / 23.00)$ and platelet on day $11.00(10.00 / 13.00)$ and $21.00(18.00 / 25.00)$, respectively; $\mathrm{p}<0.0001$ ]. The type of disease also affected engraftment, where multiple myeloma (MM) and lymphoma showed faster engraftment when compared with leukemia, syndrome myelodysplastic (SMD) and aplastic anemia (AA) and MM presented the best overall survival (OS) in a period of 12 months. Other factors included the drug used in the conditioning regimen $(\mathrm{CR})$, where CBV, melphalan (M-200) and FluCy showed faster engraftment and M-200 presented the best OS, in a period of 12 months and age, where 50-59 years demonstrated faster engraftment. Sex did not influence neutrophil and platelet recovery.

\section{Introduction}

Hematopoietic stem cell transplantation (HSCT) is a widely accepted therapeutic modality for a number of malignant,

\footnotetext{
*Correspondence to: Thissiane de Lima Gonçalves; Departamento de Análises Clínicas e Toxicológicas; CCS; Universidade Federal de Santa Maria; Santa Maria RS 97105-900 Brazil; Tel./Fax: +55.3220.8018; Email: thissi@smail.ufsm.br/ thissianegoncalves@yahoo.com.br

Submitted: 12/12/08; Revised: 03/02/09; Accepted: 03/09/09

Previously published online as an Oxidative Medicine and Cellular Longevity E-publication:

http://www.landesbioscience.com/journals/oximed/article/8355
}

hematologic, immunologic and genetic diseases. ${ }^{1}$ This therapy consists of the intravenous infusion of hematopoietic progenitor cells to reestablish marrow function in patients with damaged or defective bone marrow. Allogeneic HSCT involves the transfer of marrow from a donor to another person. It has been preferentially performed in patients with under 60 years of age, because of a higher incidence of graft-versus-host disease in older patients. Autologous HSCT involves the use of the patient's own marrow to reestablish hematopoietic cell function after the administration of high-dose chemotherapy and can be safely performed in older patients, because there is no risk of graft-versus-host disease as a complication. ${ }^{2}$

Autologous transplantation has been performed particularly in patients with multiple myeloma or lymphoma ${ }^{3,4}$ whereas allogeneic transplantation is preferred for patients with leukemias or myeloproliferative diseases. ${ }^{5}$

Graft failure or graft rejection after HSCT remains a severe complication and may be manifested as either lack of initial engraftment of donor cells, or loss of donor cells after initial engraftment. Rejection is a major cause of graft failure. Other possible causes include viral infections, drug toxicity and septicemia. The use of granulocyte-colony-stimulating factor (G-CSF) mobilized peripheral blood stem cell transplantation (PBSCT) instead of bone marrow, may reduce the rates of graft rejection, ${ }^{6}$ enhanced engraftment and accelerated hematopoietic recovery ${ }^{7-9}$ because PBSCT affords about 10-fold more T cells, ${ }^{10,11}$ compared to bone marrow, and a 2-fold higher $\mathrm{CD} 34^{+}$cell dose. However, most studies have reported a higher risk of chronic graft-versushost disease (GVHD) with allogeneic PBSCTs. ${ }^{12,13}$ In autologous HSCT, the major problem is that malignant cells, with their inherent resistance to chemotherapy, might survive and their reinfusion probably contributes to the high incidence of relapse observed after this therapy. ${ }^{14}$

Administration of high doses of chemotherapy (including busulfan, cyclophosphamide and or etoposide), with or without 
total body irradiation (TBI), is a feature of HSCT protocols, for malignant and non-malignant diseases. ${ }^{15}$ These myeloablative CRs can be more or less toxic, depending on the drug utilized. In addition, the speed and durability of engraftment are important for successful HSCT with both neutrophil $(>500 / \mu \mathrm{L})$ and platelet $(>20,000 / \mu \mathrm{L})$ reconstitution. It is important to improve our knowledge about the different factors affecting hematopoetic recovery after HSCT to further enhance the safety of this procedure. The objective of this study is to identify predictive factors affecting a rapid engraftment in patients undergoing autologous and allogeneic HSCT.

\section{Results}

In $65(100 \%)$ patients examined, 3 (04.62\%) did not present engraftment and in $62(93.94 \%)$ neutrophil and platelet engraftment occurred.

Kruskal-Wallis ANOVA followed by Mann-Whitney U test demonstrated that in terms of neutrophil and platelet engraftment there was no significant difference between the sexes. The Fisher test also showed no difference between the sexes in terms of OS in the periods of $<6$ months and 6-12 months (Table 2).

There were statistically significant differences in neutrophil and platelet engraftment between patients $<20$ years old (neutrophil) and 20-29 years old (platelet) from 50-59 years old, where neutrophil engraftment occurred more rapidly in the 50-59 year-old group, occurring in median on day $11.00(10.00 / 18.00)$ and 19.00 (16.00/29.00), respectively and platelet engraftment in median on day $13.00(10.00 / 21.00)$ and $22.00(13.00 / 25.00)$, respectively $(\mathrm{p}<0.005)$, (Table 3$)$.

The effect of disease type on engraftment was investigated. Neutrophil and platelet engraftment occurred more rapidly in MM than in leukemias, SMD and AA, neutrophil engraftment occurring in median on day $11.00(10.00 / 11.50), 18.00$ $(16.00 / 20.00)(\mathrm{p}<0.0001), 20.50(18.50 / 25.50)$ and 22.00 $(18.00 / 29.00)(\mathrm{p}<0.005)$, respectively and platelet engraftment in median on day 11.00 (10.00/13.00), 21.00 (17.00/25.00), 23.00 $(21.00 / 26.50)$ and $24.00(20.00 / 29.00)$, respectively $(\mathrm{p}<0.005)$; Neutrophil and platelet engraftment occurred more rapidly for lymphomas than for leukemias, SMD and AA, neutrophil engraftment occurring on day 10.00 (09.00/15.50), 18.00 (16.00/20.00), $20.50(18.50 / 25.50)$ and $22.00(18.00 / 29.00)$, respectively and platelet engraftment occurring on day 13.00 (10.50/16.00), 21.00 (17.00/25.00), $23.00(21.00 / 26.50)$ and 24.00 (20.00/29.00), respectively $(\mathrm{p}<0.005)$. OS presented a statistically significant difference between MM and SMD at 6-12 months, being 100\% and $62.5 \%$, respectively $(\mathrm{p}<0.05)$, (Table 4$)$. No significant differences where shown for engraftment time or for OS among the different types of leukemias or among the different types of lymphomas (data not shown).

Neutrophil and platelet engraftment occurred more rapidly in autologous PBSCT than in allogeneic BMT. Neutrophil engraftment occurred in median on day $10.00(09.00 / 11.00)$ and 19.00 $(16.00 / 23.00)$, respectively and platelet engraftment occurred in median on day $11.00(10.00 / 13.00)$ and $21.00(18.00 / 25.00)$, respectively ( $\mathrm{p}<0.0001)$, (Table 5$)$.
In relation to the effect of $\mathrm{CR}$ on engraftment, neutrophil and platelet engraftment occurred more rapidly in patients that used CBV, when compared to those using FluCy, CyTBI, $\mathrm{BuCy} 120, \mathrm{BuCy} 200$ and $\mathrm{Cy} 200$, neutrophil engraftment occurring in median on day $09.00(09.00 / 10.50), 12.50(11.50 / 16.00)$, 20.00 (17.50/21.00), 19.00 (18.00/23.00), $23.50(22.00 / 25.00)$ and $19.00(18.00 / 29.00)(\mathrm{p}<0.05)$, respectively; and neutrophil engraftment was more rapid in patients using $\mathrm{M}-200$ when compared to those using CyTBI, BuCy120, BuCy200 and Cy200 and FluCy than BuCy120 ( $\mathrm{p}<0.05)$, occurring in median on day $11.00(10.00 / 11.50)$ for M-200. Platelet engraftment occurred in median on day $11.50(10.00 / 13.00)$ for CBV, $15.50(13.50 / 17.50)$ for FluCy, 20.00 (18.00/22.00) for CyTBI, 22.00 (21.00/25.00) for $\mathrm{BuCy} 120$ and 25.00 (24.00/26.00) for BuCy200; was more rapid in patients that used $\mathrm{M}-200$ in comparison to those using FluCy, CyTBI, BuCy120 and BuCy200, occurring in median on day $11.00(10.00 / 13.00)$ for M-200; more rapid in FluCy than in $\mathrm{BuCy} 120$, $(\mathrm{p}<0.05)$. OS was significantly different between M-200 with CyTBI and BuCY200 in the period of 6-12 months, being $100 \%, 50 \%$ and $33.33 \%$ respectively $(p<0.05)$, (Table 6 ).

\section{Discussion}

Mobilized peripheral blood stem-cell transplantation (PBSCT) has largely replaced the use of bone marrow as the preferred source of hematopoietic stem-cell in autologous transplant ${ }^{16}$ and has been increasingly used in the allogeneic procedure. ${ }^{17}$ PBSCT is better than BMT with regard to hospitalization period, transplantrelated mortality and main produces a more rapid hematopoietic reconstitution ${ }^{9,13,17}$ than that using marrow derived stem-cells, probably because of the higher content of committed hematopoietic precursor cells. ${ }^{10,11,14}$ In line with this, we and other authors $9,12,13,18,19$ found a more rapid hematologic recovery, with a shorter interval of time for neutrophil and platelet engraftment with PBSCT when compared with BMT. This finding in our case specific can be due that the PBSCT enhance engraftment and accelerate hematopoietic recovery $7,8,9,13$ and all patients with PBSCT realized autologous transplantation that is a more simple proceeding when compared with BMT, because involves the use of the patient's own marrow to reestablish hematopoietic cell function. ${ }^{2}$

Allogeneic HSCT has been preferentially performed in patients under the age of 60 years, being that $40-50$ is considered old for this procedure, because of a higher incidence of complications in the older patients. On the other hand, autologous HSCT can be performed safely in older patients, because it is a more simple procedure and presents fewer complications. ${ }^{2}$ In terms of the effect of age on neutrophil and platelet engraftment, we found that engraftment was more rapid in the 50-59 year-old group. This finding could be due to the fact that the older group was also linked with some more favorable variables. For example, most of the patients in the older group underwent the more favorable autologous PBSCT (Table 3) and received M-200 and CBV, which were also associated with a faster engraftment.

In relation to the effect of disease type on engraftment, neutrophil and platelet engraftment occurred more rapidly in $\mathrm{MM}$ and in 


\section{Table 1 Pretransplantation characteristics of patients}

\begin{tabular}{|c|c|}
\hline & $\begin{array}{l}\text { Number of patients } \\
\qquad(\mathrm{n}=65)\end{array}$ \\
\hline Median age (years) & $39.23 \pm 15.13$ \\
\hline \multicolumn{2}{|l|}{ Sex } \\
\hline Male & 38 \\
\hline Female & 27 \\
\hline \multicolumn{2}{|l|}{ Diagnosis } \\
\hline Multiple myeloma & 12 \\
\hline \multicolumn{2}{|l|}{ Lymphoma } \\
\hline Hodgkin & 10 \\
\hline No Hodgkin & 11 \\
\hline \multicolumn{2}{|l|}{ Leukemia } \\
\hline Acute myeloid & 08 \\
\hline Chronic myeloid & 06 \\
\hline Acute lymphoblastic & 02 \\
\hline Myelodysplasia & 08 \\
\hline Aplastic anemia & 08 \\
\hline \multicolumn{2}{|l|}{ Graft source } \\
\hline Allogeneic BMT & 40 \\
\hline Autologous PBSCT & 25 \\
\hline \multicolumn{2}{|l|}{ Conditioning regimen } \\
\hline BuCy 120 & 19 \\
\hline BuCy 200 & 03 \\
\hline Cy 200 & 05 \\
\hline$M-200$ & 12 \\
\hline CBV & 13 \\
\hline FluCy & 04 \\
\hline BEAM & 05 \\
\hline СуТВI & 04 \\
\hline
\end{tabular}

BMT, bone marrow transplantation; PBSCT, peripheral blood stem cell transplantation; BuCy120 busulfan + cyclophosphamide $120 \mathrm{mg}$; BuCy200, busulfan + cyclophosphamide $200 \mathrm{mg} ;$ Cy200, cyclophosphamide $200 \mathrm{mg} ; \mathrm{M}-200$, melphalan $200 \mathrm{mg}$; CBV, cyclophosphamide + carmustine + etoposide; FluCy, fludarabine + cyclophosphamide; BEAM, carmustine + etoposide + arabynoside + melphalan; CyTBI, cyclophosphamide + total body irradiation.

Table 2 Influence of sex on engraftment

\begin{tabular}{lcc}
\hline & $\begin{array}{c}\text { Male } \\
(\mathbf{n}=\mathbf{3 8})\end{array}$ & $\begin{array}{c}\text { Female } \\
(\mathbf{n}=27)\end{array}$ \\
No engraftment & 01 & 02 \\
Engraftment & 37 & 25 \\
Neutrophil engraftment (day) & 13.00 & 16.00 \\
Platelet engraftment (day) & $(10.00 / 19.00)$ & $(11.00 / 19.00)$ \\
OS (<6 months) & 16.00 & 20.00 \\
OS (6-12 months) & $36 / 38(94.74 \%)$ & $23 / 27(85.18 \%)$ \\
& $31 / 38(81.58 \%)$ & $21 / 27(77.78 \%)$
\end{tabular}

OS: overall survival; Neutrophil and platelet engraftment were expressed as median (lower/upper quartile). lymphomas when compared with leukemias, SMD and AA. This may also be due to association with other more favorable factors, i.e., patients with MM and Hodgkin or no-Hodgkin lymphoma, mainly underwent autologous PBSCT, with M-200 and CBV, which showed more rapid engraftment than the allogeneic HSCT with other drugs utilized in the CRs for leukemias, SMD and AA patients. The same occurred in OS, where patients with MM showed a better OS than that for SMD, probably because of its association with variables such as autologous PBSCT, and the use of M-200. Carral et al. ${ }^{20}$ showed that the leukemia group had a delayed hematopoietic recovery when compared with MM and lymphomas and suggested that residual leukemia in the patient may also contribute to delayed engraftment.

The objective of clinical research is to find chemotherapy drugs that produces minimal toxic effects on normal tissue. Today, chemotherapy is performed with a combination of drugs, because it allows maximal cellular death with tolerable toxic limits and avoids cell resistance. ${ }^{21}$ In this study, it can be observed that CBV, M-200 and FluCy produced better engraftment than the other CRs with high doses of cyclophosphamide or the presence of busulfan cytostatic drugs. The OS was also better in M-200 patients than in those using other drugs such as CyTBI and $\mathrm{BuCy} 200$, probably because of Cy and TBI toxicity. In the case of FluCy, Srinivasan et al. ${ }^{22}$ demonstrated that fludarabine associated to cyclophosphamide helped achieve engraftment, allowing a reduction of the traditionally high dose of cyclophosphamide. The same authors indicated that fludarabine increased engraftment rates, and showed minimal morbidity. ${ }^{23-26}$ George et al. ${ }^{27}$ observed that fludarabine improved OS in children with AA.

In summary, our study shows that the most important variable influencing engraftment in patients undergoing HSCT was the source, being that autologous PBSCT resulted in faster neutrophil and platelet engraftment. Another important variable was the CR, where CBV, M-200 and FluCy produced faster neutrophil and platelet engraftment. Other variables such as disease type and age that showed an influence were probably associated with the source and CR utilized in HSCT.

\section{Materials and Methods}

Patients. This is a retrospective study, where 25 patients who were undergoing autologous HSCT and 40 undergoing allogeneic HSCT, in the onco-hematology unit of the Hospital Universitario of the Universidade Federal de Santa Maria, Brazil, between January 2006 and December 2007, were investigated. The information about factors affecting the engraftment in HSCT patients were taken from patient files.

The present study was approved by the Human Ethical Committee of the Universidade Federal de Santa Maria, protocol number: 0152.0.243.000-06.

Table 1 shows the pre-transplant characteristics, graft source and the conditioning regimens of patients undergoing autologous and allogeneic HSCT.

Conditioning regimens. The patients were divided in conditioning regimen groups according to diseases and HSCT sources. M-200: melphalan $\left(200 \mathrm{mg} / \mathrm{m}^{2}\right)$ given only for 1 day (day minus 
Table 3 Influence of age on engraftment

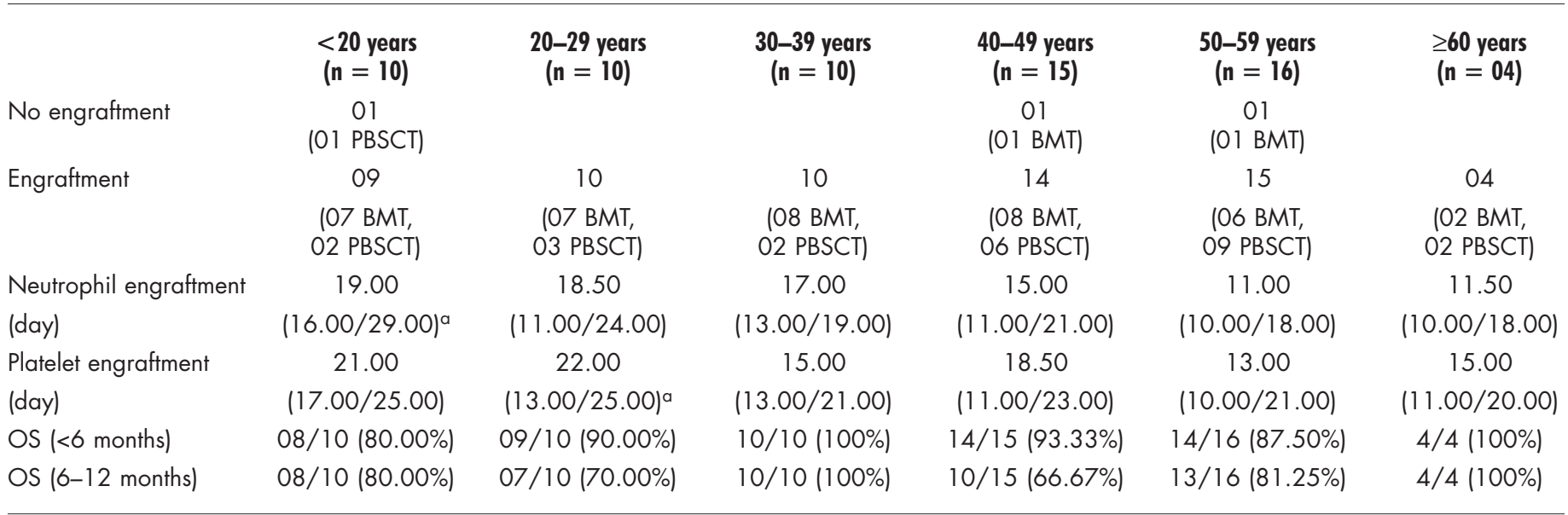

OS: overall survival; Neutrophil and platelet engraftment were expressed as median (lower/upper quartile). aSignificantly different from 50-59 years old.

Table 4 Influence of disease type on engraftment

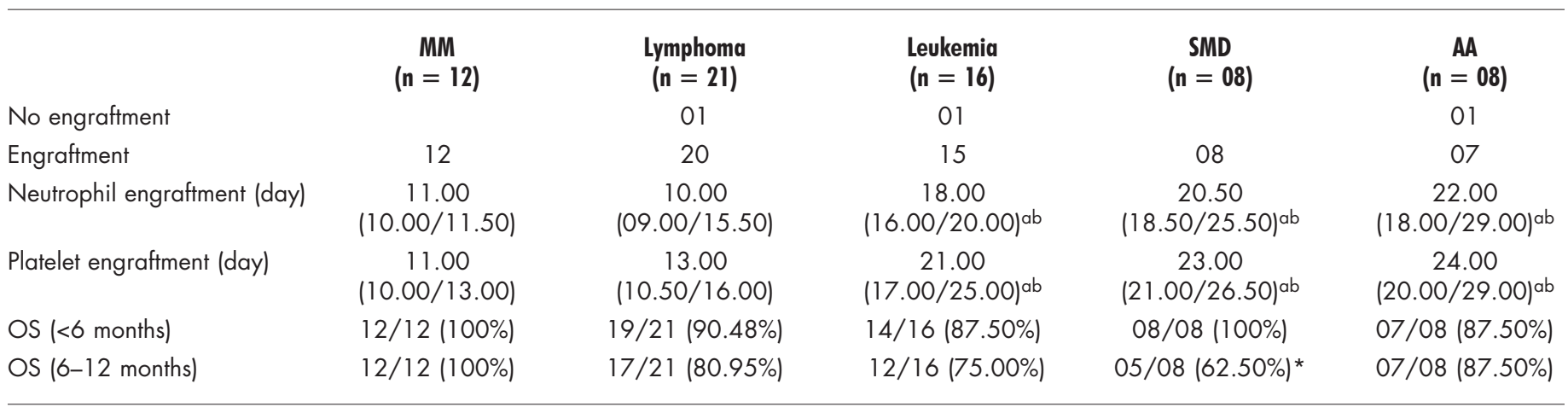

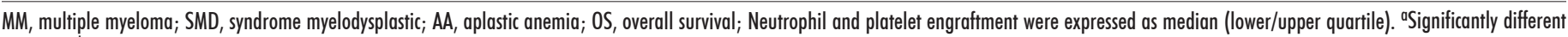
from MM. 'bignificantly different from Lymphoma. ${ }^{*}$ OS significantly different from MM.

3) before the transplantation for multiple myeloma in PBSCT. CBV: cyclophosphamide $\left(1,500 \mathrm{mg} / \mathrm{m}^{2}\right)$ given for 4 consecutive days starting 6 days before the transplantation (days minus 6 to minus 3) + carmustine (BCNU-450 mg/m²) given only for 1 day before the transplantation (day minus 6) + etoposide $\left(\mathrm{VP}-16-250 \mathrm{mg} / \mathrm{m}^{2}\right.$ ) given for 3 consecutive days two times a day, starting 6 days before the transplantation (days minus 6 to minus 4) or BEAM: carmustine (BCNU-300 mg/m²) given only for 1 day before the transplantation (day minus 7 ) + etoposide (VP-16-200 $\mathrm{mg} / \mathrm{m}^{2}$ ) given for 4 consecutive days two times a day, starting 6 days before the transplantation (days minus 6 to minus 3$)+$ cytarabine $\left(100 \mathrm{mg} / \mathrm{m}^{2}\right)$ given for 4 consecutive days two times a day, starting 6 days before the transplantation (days minus 6 to minus 3$)+$ melphalan $\left(140 \mathrm{mg} / \mathrm{m}^{2}\right)$ given only for 1 day before the transplantation (day minus 6) for Hodgkin and non-Hodgnkin lymphomas in PBSCT. FluCy: fludarabine $\left(30 \mathrm{mg} / \mathrm{m}^{2}\right)+$ cyclophosphamide $\left(300 \mathrm{mg} / \mathrm{m}^{2}\right)$, both given for 3 consecutive days, starting 4 days before the transplantation (days minus 4 to minus 2) for Hodgkin and non-Hodgnkin lymphomas in BMT. BuCy120: busulfan (1 mg/kg), given for 4 consecutive days, four times a day, starting 8 days before the
Table 5 Influence of transplantation type and graft source on engraftment

\begin{tabular}{lcc}
\hline & $\begin{array}{c}\text { Allogeneic BMT } \\
(\mathbf{n}=40)\end{array}$ & $\begin{array}{c}\text { Autologous PBSCT } \\
(\mathbf{n}=25)\end{array}$ \\
No engraftment & 02 & 01 \\
Engraftment & 38 & 24 \\
Neutrophil engraftment (day) & 19.00 & 10.00 \\
& $(16.00 / 23.00)$ & $(09.00 / 11.00)^{a}$ \\
Platelet engraftment (day) & 21.00 & 11.00 \\
OS (<6 months) & $(18.00 / 25.00)$ & $(10.00 / 13.00)^{a}$ \\
OS (6-12 months) & $34 / 40(85.00 \%)$ & $24 / 25(96.00 \%)$ \\
& $31 / 40(77.50 \%)$ & $22 / 25(88.00 \%)$
\end{tabular}

BMT, bone marrow transplantation; PBSCT, peripheral blood stem cell transplantation; OS, overall survival; Neutrophil and platelet engraftment were expressed as median (lower/upper quartile). a'significantly different between Allogeneic BMT and Autologous PBSCT.

transplantation (days minus 8 to minus 5 ) + cyclophosphamide $\left(60 \mathrm{mg} / \mathrm{m}^{2}\right)$, given for 2 consecutive days, starting 4 days before the transplantation (days minus 4 to minus 3) for acute and 
Table 6 Influence of conditioning regimen on engraftment

\begin{tabular}{|c|c|c|c|c|c|c|c|c|}
\hline & $\begin{array}{c}M-200 \\
(n=12)\end{array}$ & $\begin{array}{c}\text { CBV } \\
(n=13)\end{array}$ & $\begin{array}{c}\text { BEAM } \\
(n=05)\end{array}$ & $\begin{array}{c}\text { FluCy } \\
(n=04)\end{array}$ & $\begin{array}{l}\text { BuCy120 } \\
(n=19)\end{array}$ & $\begin{array}{l}\text { BuCy200 } \\
(n=03)\end{array}$ & $\begin{array}{c}\text { Cy200 } \\
(n=05)\end{array}$ & $\begin{array}{c}\text { CyTBI } \\
(n=04)\end{array}$ \\
\hline No engraftment & & 01 & & & 01 & 01 & & \\
\hline engraftment & 12 & 12 & 05 & 04 & 18 & 02 & 05 & 04 \\
\hline $\begin{array}{l}\text { Neutrophil } \\
\text { engraftment } \\
\text { (day) }\end{array}$ & $\begin{array}{c}11.00 \\
(10.00 / 11.50)^{d}\end{array}$ & $\begin{array}{c}09.00 \\
(09.00 / 10.50)^{\text {ad }}\end{array}$ & $\begin{array}{c}19.00 \\
(10.00 / 24.00)^{\mathrm{ab}}\end{array}$ & $\begin{array}{c}12.50 \\
(11.50 / 16.00)^{b}\end{array}$ & $\begin{array}{c}19.00 \\
(18.00 / 23.00)^{\mathrm{cab}}\end{array}$ & $\begin{array}{c}23.50 \\
(22.00 / 25.00)^{\mathrm{cab}}\end{array}$ & $\begin{array}{c}19.00 \\
(18.00 / \\
29.00)\end{array}$ & $\begin{array}{c}20.00 \\
(17.50 / \\
21.00)^{\mathrm{cab}}\end{array}$ \\
\hline $\begin{array}{l}\text { Platelet } \\
\text { engraftment } \\
\text { (day) }\end{array}$ & $\begin{array}{c}11.00 \\
(10.00 / 13.00)^{d}\end{array}$ & $\begin{array}{c}11.50 \\
(10.00 / 13.00)^{\mathrm{ad}}\end{array}$ & $\begin{array}{c}20.00 \\
(11.00 / 24.00)^{\mathrm{ab}}\end{array}$ & $\begin{array}{c}15.50 \\
(13.50 / 17.50)^{\mathrm{b}}\end{array}$ & $\begin{array}{c}22.00 \\
(21.00 / 25.00)^{\mathrm{cab}}\end{array}$ & $\begin{array}{c}25.00 \\
(24.00 / 26.00)^{\mathrm{cab}}\end{array}$ & $\begin{array}{c}22.00 \\
(20.00 / \\
29.00)\end{array}$ & $\begin{array}{c}20.00 \\
(18.00 / \\
22.00)^{\mathrm{cab}}\end{array}$ \\
\hline $\begin{array}{l}\text { OS } \\
\text { (<6 months) }\end{array}$ & $12 / 12$ (100\%) & $12 / 13(92.30 \%)$ & 04/05 (80.00\%) & 04/04 (100\%) & $18 / 19(94.74 \%)$ & $02 / 03(66.67 \%)$ & $\begin{array}{l}04 / 05 \\
(80 \%)\end{array}$ & $\begin{array}{c}03 / 04 \\
(75.00 \%)\end{array}$ \\
\hline $\begin{array}{l}\text { OS } \\
\text { (6-12 months) }\end{array}$ & $12 / 12(100 \%)$ & $10 / 13(76.92 \%)$ & $04 / 05(80.00 \%)$ & 04/04 (100\%) & $15 / 19(78.95 \%)$ & $01 / 03(33.33 \%)^{*}$ & $\begin{array}{l}04 / 05 \\
(80 \%)\end{array}$ & $\begin{array}{c}02 / 04 \\
(50.00 \%)^{*}\end{array}$ \\
\hline
\end{tabular}

M-200, melphalan $200 \mathrm{mg}$; CBV, cyclophosphamide + BCNU + etoposide; BEAM, BCNU + etoposide + arabynoside + melphalan; FluCy, fludarabine + cyclophosphamide; BuCy120, busulfan + cyclophosphamide $120 \mathrm{mg}$; BuCy200, busulfan + cyclophosphamide $200 \mathrm{mg}$; Cy200, cyclophosphamide $200 \mathrm{mg}$; CyTBI, cyclophosphamide + total body irradiation. Data were expressed as median (lower/upper quartile). aSignificantly different from M-200. 'bignificantly different from CBV. SSignificantly different from FluCy. ${ }^{d}$ Significantly different from Cy200. *0S significantly different from M-200.

chronic myeloid leukemia and syndrome myelodysplastic in BMT. BuCy200: busulfan $(1 \mathrm{mg} / \mathrm{kg})$, given for 3 consecutive days four times a day, starting 9 days before the transplantation (days minus 9 to minus 7$)+$ cyclophosphamide $\left(50 \mathrm{mg} / \mathrm{m}^{2}\right)$, given for 4 consecutive days, starting 6 days before the transplantation (days minus 6 to minus 3) or Cy200: cyclophosphamide $\left(40 \mathrm{mg} / \mathrm{m}^{2}\right)$, given for 5 consecutive days, starting 5 days before the transplantation (days minus 5 to minus 1) for aplastic anemia in BMT. CyTBI: cyclophosphamide $\left(60 \mathrm{mg} / \mathrm{m}^{2}\right)$, given for 2 consecutive days, starting 7 days before the transplantation (days minus 7 to minus 6) + total body irradiation, made for 4 consecutive days, starting 4 days before the transplantation (days minus 4 to minus 2, three times on day and day minus 1 , two times on day) for acute and chronic lymphoid leukemia in BMT. All patients had 2 rest days (without chemotherapy) before the transplantation (days minus 2 and minus 1), except FluCy and CyTBI CR patients, that had only one rest day (day minus 1 and minus 5, respectively).

Engraftment. Neutrophil engraftment was defined as the first of three consecutive days post-transplant with neutrophil counts $>500 / \mathrm{mm}^{3}$, while platelet engraftment was defined as first of three consecutive days post-transplant untransfused platelets, with counts $>20,000 / \mathrm{mm}^{3}$.

Statistical analysis. Sex, age, disease, graft source and conditioning regimens were examined in terms of their effect on neutrophil and platelet engraftment.

Variables were compared using Kruskal-Wallis ANOVA followed by Mann-Whitney $\mathrm{U}$ test. Overall survival was estimated using the Fisher test.

p-value $<0.05$ was considered statistically significant.

\section{Acknowledgements}

The authors thanks CNPq, CAPES and FAPERGS for support in this study.

\section{References}

1. Milla C, Yang S, Cornfiel DN, Brennan ML, Hazen SL, Mortari AP, et al. Myeloperoxidase deficiency enhances inflammation after allogenic marrow transplantation. Am J Physiol Lung Cell Mol Physiol 2004; 287:706-14.

2. Armitage JO. Medical progress: Bone marrow transplantation. N Engl J Med 1994; 330:827-38.

3. Horning SJ, Nademanee AP. Autologous hematopoietic cell transplantation for nonHodgking lymphoma. Blackwell Science 1999; 939-51.

4. Oyan B, Koc Y, Ozdemir E. Ifosfamide, idarubicin and etoposide in relapsed/refractory Hodgkin disease or non-Hodgking lymphoma: A savage regimen with high response rates before autologous stem cell transplantation. Biol Blood Marrow Transplant 2005; 11:688-97.

5. Clift RA, Anasetti C. Allografting for chronic myeloid leukaemia. Baillieres Clin Haematol 1997; 10:319-36.

6. Mattsson J, Ringdén O, Storb R. Graft failure after allogeneic hematopoietic cell transplantation. Biol Blood Marrow Transplant 2008; 14:165-70.

7. Beyer J, Schwella N, Zingsem J, Strohscheer I, Schwaner I, Oettle H, et al. Hematopoietic rescue after high-dose chemotherapy using autologous peripheral-blood progenitor cells or bone marrow: A randomized comparison. J Clin Oncol 1995; 13:1328-35.

8. Hartmann O, Le Corroler AG, Blaise D, Michon J, Philip I, Norol F, et al. Peripheral blood stem cell and bone marrow transplantation for solid tumors and lymphomas: hematologic recovery and costs—A randomizad, controlled trial. Ann Intern Med 1997; 126:600-7.

9. Champlin RE, Schmitz N, Horowitz MM, Chapuis B, Chopra R, Cornelissen JJ, et al. Blood stem cells compared with bone marrow as a source of hematopoietic cells for allogeneic transportation. Blood 2000; 95:3702-9.

10. Bensinger WI, Weaver CH, Appelbaum FR, Rowley S, Demirer T, Sanders J, et al. Transplantation of allogeneic peripheral blood stem cells mobilized by recombinant human granulocyte colony-stimulating factor. Blood 1995; 85:1655-8.

11. Tayebi H, Lapierre V, Saas P, Lienard A, Sutton L, Milpied N, et al. Enhanced activation of B cells in a granulocyte colony-stimulating factor-mobilized peripheral blood stem cell graft. Br J Haematol 2001; 114:698-700.

12. Robinet E, Lapierre V, Tayebi H, Kuentz M, Blaise D, Tiberghien P. Blood versus marrow hematopoietic allogeneic graft. Transfusion and Apheresis Science 2003; 29:53-9.

13. Ghavamzadeh A, Iravani M, Ashouri A, Mousavi SA, Mahdavi N, Shamshiri A, et al. Peripheral blood versus bone marrow as a source of hematopoietic stem cells for allogeneic transplantation in children with class I and II beta thalassemia major. Biol Blood Marrow Transplant 2008; 14:301-8.

14. Devetten M, Armitage JO. Hematopoietic cell transplantation: Progress and obstacles. Ann Oncol 2007; 18:1450-6.

15. Ziegler TM. Glutamine supplementation in bone marrow transplantation. Br J Nutrition 2002; 87:9-15.

16. Rizzo JD. Current trends in BMT. ABMTR News Letter 1998; 5:4-10.

17. Bacigalupo A, Zikos P, Van Lint MT, Valbonesi M, Lamaprelli T, Gualandi F, et al. Allogeneic bone marrow or peripheral blood cell transplants in adults with hematologic malignancies: a single-center experience. Exp Hematol 1998; 26:409-14. 
18. Bensinger WI, Clift R, Martin P, Appelbaum FR, Demirer T, Gooley T, et al. Allogeneic peripheral blood stem cell transplantation in patients with advanced henatologic malignancies: a retrospective comparison with marrow transplantation. Blood 1996; 88:2794-800.

19. Storek J, Dawson MA, Storer B, Stevens-Ayers T, Maloney DG, Marr KA, et al. Immune reconstitution after allogeneic marrow transplantation compared with blood stem cell transplantation. Blood 2001; 97:3380-9.

20. Carral A, de la Rubia J, Martãn G, Martãnez J, Sanz G, Jarque I, et al. Factors influencing hematopoietic recovery after blood stem cell transplantation in patients with acute myeloblastic leukemia and with non-myeloid malignancies. Bone Marrow Transplant 2002; 29:825-32.

21. Filho JAO, Garcia AHR. Câncer colorretal: Tratamento quimioterápico adjuvante e na doença metastática. In: Guimarāes JRQ, Manual de Oncologia. $3^{\text {th }}$ Ed. São Paulo, SP:BBS 2006; 85-7.

22. Srinivasan R, Takahashi Y, Mccoy JP, Espinoza-Delgado I, Dorrance C, Igarashi T, et al. Overcoming graft rejection in heavily trasnfused and allo-immunised patients with bone marrow failure syndromes using fludarabine-based haematopoietic cell transplantation. Br J Haematol 2006; 133:305-14.

23. Slavin S, Nagler A, Naparstek E, Kapelushnik Y, Aker M, Cividalli G, et al. Nonmyeloblative stem cell transplantation and cell therapy as an alternative to conventional bone marrow transplantation with lethal cytoreduction for the treatment of malignant and nonmalignant hematologic disease. Blood 1998; 91:756-63.

24. Childs R, Chernoff A, Contentin N, Bahceci E, Schrump D, Leitman S, et al. Regression of metastic renal-cell carcinoma after nonmyeloblative allogenic peripheral-blood stemcell transplantation. New England Journal of Medicine 2000; 343:750-8.

25. Niederwieser D, Maris M, Shizuru JA, Petersdorf E, Hegenbart U, Sandmaier BM, et al. Low-dose total irradiation (TBI) and fludarabine followed by hematopoietic cell transplantation (HCT) from HLA-matched or mis-matched unrelated donors and postgrafting immunosuppression with cyclosporine and mycophenolato mofetil (MMF) can induce durable complete chimerism and sustained remissions in patients with hematological diseases. Blood 2003; 101:1620-9.

26. Kang HJ, Shin HY, Choi HS, Ahn HS. Fludarabine, cyclophosphamide plus thymoglobulin conditioning regimen for unrelated bone marrow transplantation in severe aplastic anemia. Bone Marrow Transplant 2004; 34:939-43.

27. George B, Mathews V, Viswabandya A, Kavitha ML, Srivastava A, Chandy M. Fludarabine based reduced intensity conditioning regimens in children undergoing allogeneic stem cell transplantation for severe aplastic anemia. Pediatr transplant 2008; 12:14-9. 


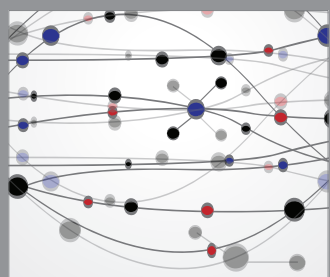

The Scientific World Journal
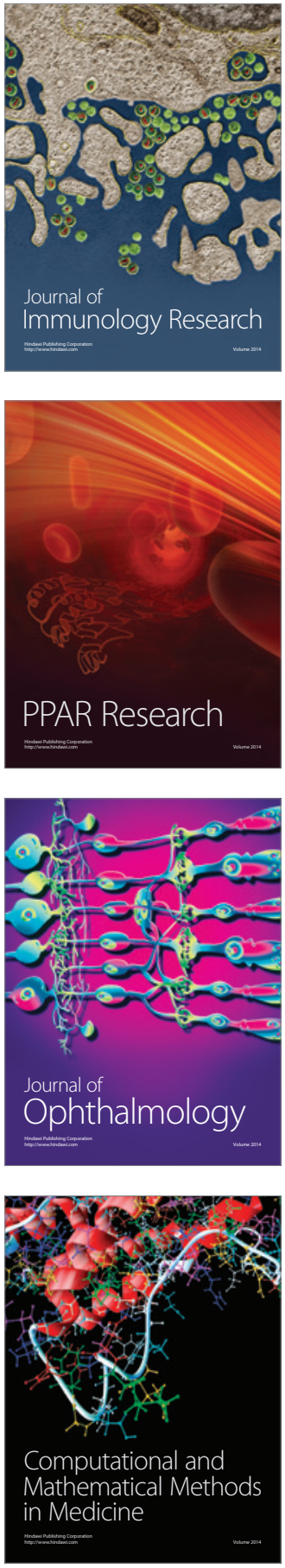

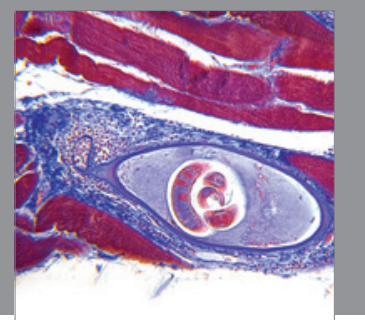

Gastroenterology

Research and Practice
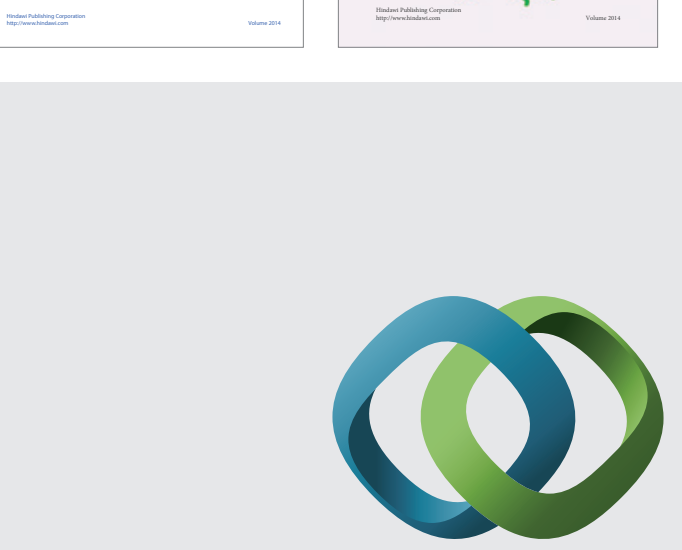

\section{Hindawi}

Submit your manuscripts at

http://www.hindawi.com
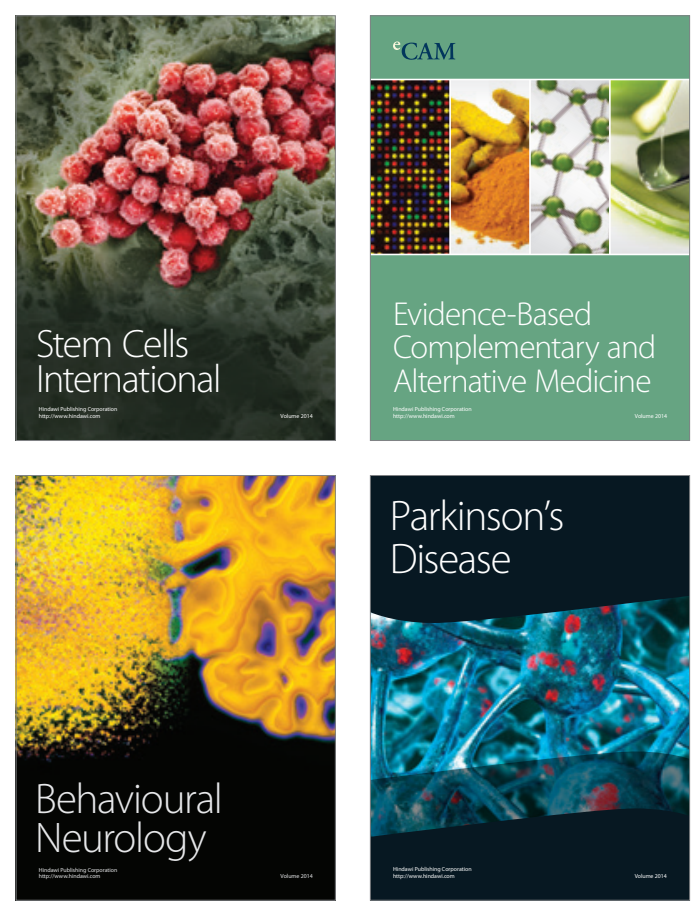

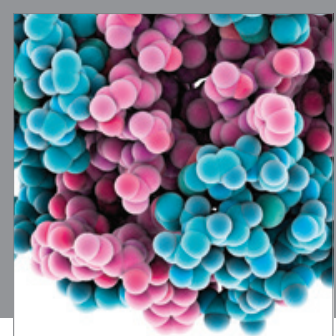

Journal of
Diabetes Research

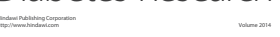

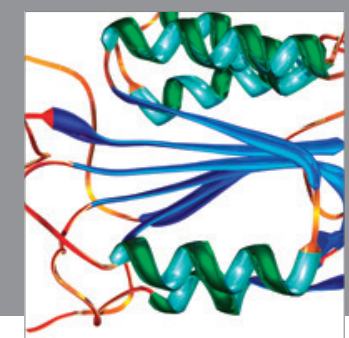

Disease Markers
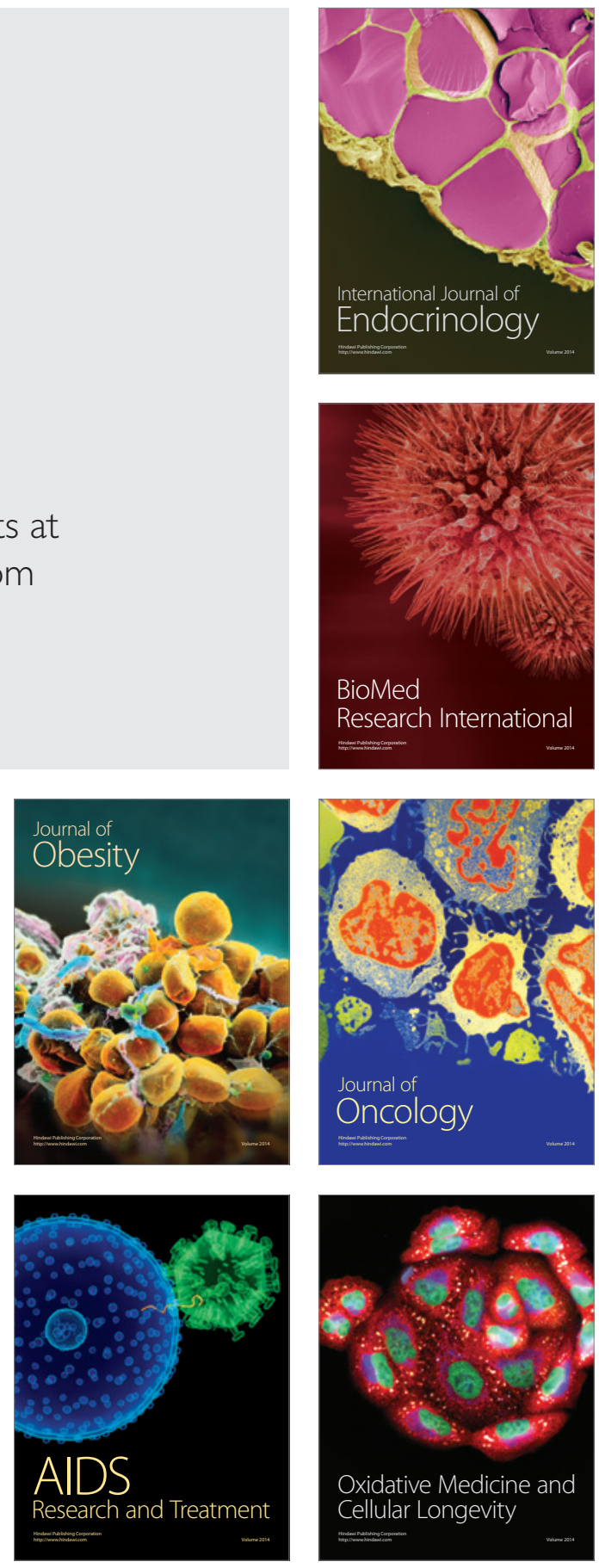